Original Article

\title{
ANTIDYSLIPIDEMIA AND ANTIOXIDANT ACTIVITY OF ANDROGRAPHOLIDE COMPOUND FROM SAMBILOTO (ANDROGRAPHIS PANICULATA) HERB
}

\author{
NI KADEK WARDITIANI", NI MADE PITRI SUSANTI*, COKORDA ISTRI SRI ARISANTI*, NI PUTU RIKA DHARMA \\ PUTRI $^{*}$, I MADE AGUS GELGEL WIRASUTA*
}

${ }^{*}$ Department of Pharmacy, Faculty of Mathematics and Natural Sciences, Udayana University, Bali, Indonesia 80361

Email: kadektia@unud.ac.id

Received: 23 Feb 2017 Revised and Accepted: 19 May 2017

\section{ABSTRACT}

Objective: The aim of this study was to observe the antidyslipidemic and antioxidant activity of andrographolide (AND) compound from Sambiloto (Andrographis paniculata) herb. The antidyslipidemic activity could be described by lowering TC (total cholesterol), TG (triglyceride), and LDL (lowdensity lipoprotein) level in the blood and by increasing HDL (high-density lipoprotein) level in the blood. The antioxidant activity could be described by inhibiting the ox-LDL (oxidized low-density lipoprotein) formation.

Methods: AND was separated from the sambiloto ethanolic extract. Atherosclerosis in rats was induced by rich fat food (5\% yolk, 10\% lard), $1 \%$ calcium and $20.000 \mathrm{IU}$ vitamin D3 for $90 \mathrm{~d}$. The rats were treated with AND compound on the 61st day for $30 \mathrm{~d}$. On the 90 th day, the blood of rats had been collected, and its blood vessel was also extracted. Antidyslipidemic activity was measured by estimating the level of TC, TG, LDL and HDL in the blood. Antioxidant activity was measured by calculating the ox-LDL concentration in blood and histopathology parameter.

Results: $18 \mathrm{mg} / \mathrm{kg}$ BW AND could reduce the level TC, TG, and LDL in blood, and could increase HDL blood level significantly ( $<<0.05$ ). This compound can also significantly inhibit LDL oxidation $(\mathrm{p}<0.05)$, and the histopathology result showed that this compound could protect the vessel from adhesive lipid plaques.

Conclusion: AND compound from sambiloto herb showed the antidyslipidemic and antioxidant effect in atherogenic rats.

Keywords: Andrographolide, Antidyslipidemic, Antioxidant, Atherosclerosis, Sambiloto Herb

(C) 2017 The Authors. Published by Innovare Academic Sciences Pvt Ltd. This is an open access article under the CC BY license (http://creativecommons.org/licenses/by/4.0/) DOI: http://dx.doi.org/10.22159/ijpps.2017v9i7.18109

\section{INTRODUCTION}

Sambiloto is one of traditional plant medicine that has been used widely by Indonesian people due to its various pharmacology effects such as anti-cancer, anti-influenza, anti-inflammatory, anti-malaria, anti-viral, anti-hepatotoxic [1]. Sambiloto or king bitter is not only used by Indonesian people but also people in another country like Indian, Pakistan, Taiwan and China to treat many diseases like a common cold, liver disorder, colic pain and bowel problem in children [2,3].

This plant contains some secondary metabolites such as flavonoids, terpenes, glycoside, saponin and tannin. AND is one of a compound that is contained in the sambiloto plant. AND is classified as diterpene lactone as a major content in this plant. AND is abundantly contained in its leaf and purified Andrographis paniculata extract [4].

Dyslipidemia is an abnormal condition in which TC, TG, and LDL level increase in the blood. Otherwise, the HDL level decreases in blood. Excess of TC in the blood will pile up in vessel's wall. Gradually, this condition could trigger atherosclerosis, conditions that make the arteries narrow and the blood flow is disrupted [5]. With high LDL level in blood for a long term, LDL will be able to infiltrate and will be trapped in the blood vessel wall. LDL which penetrates in blood vessel wall will lead up to some process series (e. g., LDL oxidation, monocyte migration, macrophage uptake of modified LDL, foam cells, fatty streaks, etc.). These will develop into a fibrous plaque inside the intima wall. Atherosclerosis is thickening and hardening process of arterial blood vessels that progress progressively as a result of cholesterol clumps in the blood vessels and due to the inflammatory response [6]. It is known that oxidized LDL plays a major role in fatty plaques formation in the arteries. Allegedly oxidized LDL triggers atherosclerosis through mechanisms that cause inflammatory and immunological dysregulation of lipid complexes and foam cell formation. There are four mechanisms involved in that process, i.e., a) endothelial dysfunction, b) foam cell formation, c) migration and proliferation of SMCs, d) induce platelet adhesion and aggregation [7]. The main pathophysiologic LDL is to deliver cholesterol to the blood vessels' smooth muscle cells (CMC) and macrophages, which will form the foam cells in the development of atherosclerosis.

Based on Martha et al. (2008), the rabbit will have atherosclerosis after being fed with atherogenic diet for $60 \mathrm{~d}$ [8]. The atherogenic diet consists of $2 \mathrm{~g}$ of cholesterol, $8 \mathrm{~g}$ of saturated fat and $100 \mathrm{mg}$ of calcium that were mixed with a commercial diet. High-fat diet could induce LDL to increase and systemic oxidative stress [23]. Also, atherosclerosis develops in the rats with very high vitamin D3 supplementation together with atherogenic diet [9].

The objective of this study was to observe the antidyslipidemic and antioxidant activity by AND compound from Sambiloto, which this study did not exist yet. This study describes the ability of AND in preventing atherosclerosis in rats by antioxidant activity as an inhibitor of oxLDL, antidyslipidemic, and to repair rat's aorta morphology. The antidyslipidemic and inhibition ox-LDL ability of AND will prevent and inhibit severity of atherosclerosis condition that is indicated by the improvement of rat's aorta morphology which is the novelty of this study.

\section{MATERIALS AND METHODS}

\section{Chemicals and reagents}

$20 \mathrm{mg}$ Atorvastatin, a drug containing atorvastatin $(20 \mathrm{mg}$, excipient: lactose) was used, Cholesterol assay kit (DiaSys Diagnostic System), Trigliserida assay kit (DiaSys Diagnostic System), HDLprecipitant (DiaSys Diagnostic System), LDL-precipitant (DiaSys Diagnostic System), Rat Oxidized Low-Density Lipoprotein (OxLDL ELISA Kit) were purchased from Genetika Science, Ethanol 96\%, chloroform, methanol p. a, silica gel powder were purchased from Kurniajaya Multisentosa, vitamin D3 was obtained from DSM.

\section{Plant material}

Sambiloto was obtained from Girimulyo village, Nanggulan area, Kulonprogo regency, Yogyakarta, Indonesia. This plant was 
identified and authenticated by a botanist at the Pharmaceutical Biology Laboratory, Faculty of Pharmacy, Gadjah Mada University, Indonesia voucher BF/143/Ident/Det/VII. The whole plant, except roots, was used in the experiment. The plant is dried by drying and then reducing it to powder size with a blender.

\section{Animals for experiment}

Wistar male albino rats, aged one month, $160 \pm 20 \mathrm{~g}$ of weight, maintained under controlled condition, were used in the experiment. The rats were fed with standard diet and given drink ad libitum. Ethical Clearance of the animal's handling was approved by the Faculty of Veterinary, Udayana University no: 240/KE-PH-Lit-1/V/2016.

\section{Extraction and separation AND compound from sambiloto}

Dried powder of Sambiloto was macerated in $96 \%$ ethanol for $24 \mathrm{~h}$, filtered, and its filtrate was then re-macerated three times. The macerate was then evaporated in a rotary evaporator to produce concentrated product. This extract is mixed with silica powder before extraction using chloroform organic solvent soxhletation. The process will end if the chloroform organic solvent became clear. The mixed silica powder and the extract are dissolved with warm methanol organic solvent. AND compound was found through the recrystallization process. The AND truth was checked by AND compound melting point check.

\section{Induction of atherosclerosis and administration of extract}

Twenty Wistar male albino rats were divided into four groups. Animals were then grouped as following:

-Grup A is AND group, rats were fed the atherogenic diet containing $15 \%$ pig fat, $10 \%$ yolk, $1 \%$ calcium, and vitamin D3 (20,000 IU weekly) for 90 $\mathrm{d}$ and received $18 \mathrm{mg} / \mathrm{kg}$ BW AND orally start from the 60th days.
-Group B is atorvastatin group, rats were fed the atherogenic diet containing $15 \%$ pig fat, $10 \%$ yolk, $1 \%$ calcium, and vitamin D3 (20,000 IU weekly) for $90 \mathrm{~d}$ and received $7.2 \mathrm{mg} / \mathrm{kg}$ BW atorvastatin orally start from the 60 th days

-Group $\mathrm{C}$ is atherogenic group, rats were fed the atherogenic diet containing $15 \%$ pig fat, $10 \%$ yolk, $1 \%$ calcium, and vitamin D3 $(20,000 \mathrm{IU}$ weekly) for $90 \mathrm{~d}$ and received $10 \mathrm{ml} / \mathrm{kg} \mathrm{BW} \mathrm{CMC-Na}$ $0.01 \%$ orally start from the 60 th days

-Group D is a normal group, rats were fed normal diet.

A blood sample was collected from retro-orbital vena. Serum was removed for determination of the lipid blood level (TC, TG, LDL, and HDL) and ox-LDL level. The rats were then sacrificed, and their aortas were prepared for histopathological observation.

\section{Lipid levels in the blood}

Lipid levels in the blood serum of rats were measured using spectrophotometry. Reagents were added to the rat serum, incubation, and measurement.

\section{Histopathology}

All rats were sacrificed, and their aortas were isolated for histological preparation. The aorta samples were fixed in $10 \%$ formaldehyde solution, and their slides were prepared. The slide preparations (6-8 $\mu \mathrm{m}$ thickness) were stained with hematoxylin/eosin. Each slide was scored based on the aorta conditions. The scores ranged from $0-4$ with the following criteria: 0 normal condition; 1 if elastic fibres thickening was found; 2 if elastic fibres fragmentation, some foam cells, and fibrosis were found; 3 if smooth muscle proliferation was found, and 4 if plaque ulceration or plaque lipid calcification was found [10].
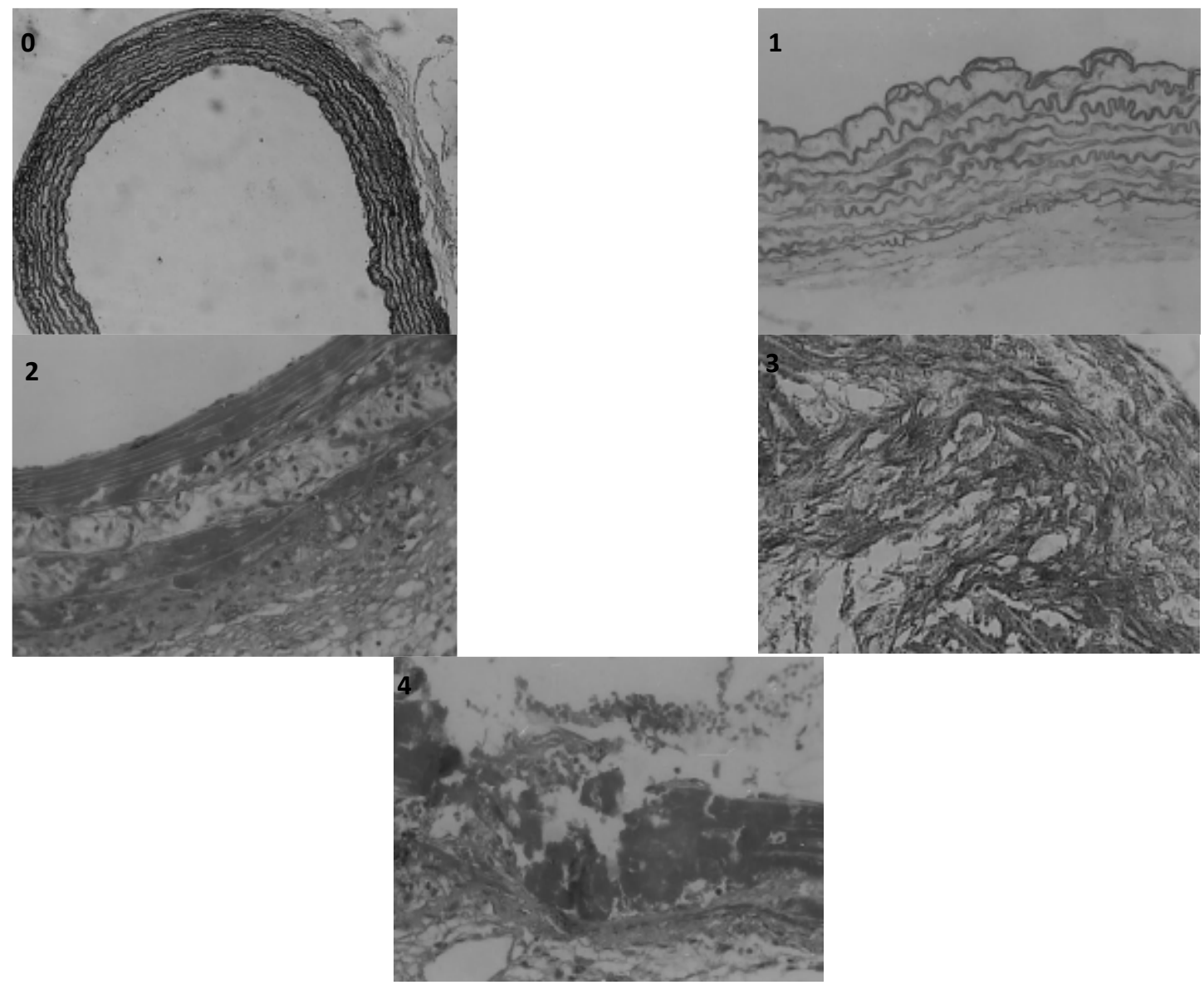

Fig. 1: Morphological structure of aorta in rats. $0=$ No lesions (normal condition), $100 x$ magnification; 1 = widening of the first interlamellar, $250 \times$ magnification; 2 = fragmentation of elastic lamellae with numerous foam cells and fibrosis, 250x magnification; $3=$ proliferation of smooth muscle cells, $400 \times$ magnification; 4 = ulcerated atherosclerotic, $250 \mathrm{x}$ magnification [10] 


\section{Ox-LDL measured}

Ox-LDL concentration in blood was measured by ELISA (Enzymelinked immunosorbent assay). Rats' serum was separated from its whole blood. The principle of this method was caused by antigen and antibody interaction with the enzyme as a marker. This enzyme would make the color change. This enzyme would help the reaction of antigen and antibody. Antigen and antibody reaction could be detected by the intensity of the color. Quantification of ox-LDL concentration would be known by a linear regression equation. This equation was made by using ox-LDL standard measurement.

\section{RESULTS}

\section{Lipid profile of rats}

TC, TG and LDL blood level was increasing due to atherogenic diet for $60 \mathrm{~d}$. At the same time, HDL blood level was decreasing due to atherogenic diet for $60 \mathrm{~d}$ (fig. 2). $18 \mathrm{mg} / \mathrm{kg}$ BW AND and $7.2 \mathrm{mg} / \mathrm{kg}$ BW atorvastatin had been fed for the next $30 \mathrm{~d}$. The effect of AND could significantly decrease lipid profile of TG, TC and LDL compared to the atherogenic group $(p<0.05)$ but not significantly different with normal group ( $p>0.05$ ). AND could also significantly increase HDL level compared to the atherogenic group $(p<0.05)$ and has the same result with normal group ( $p>0.05)$ (fig. 3$)$.

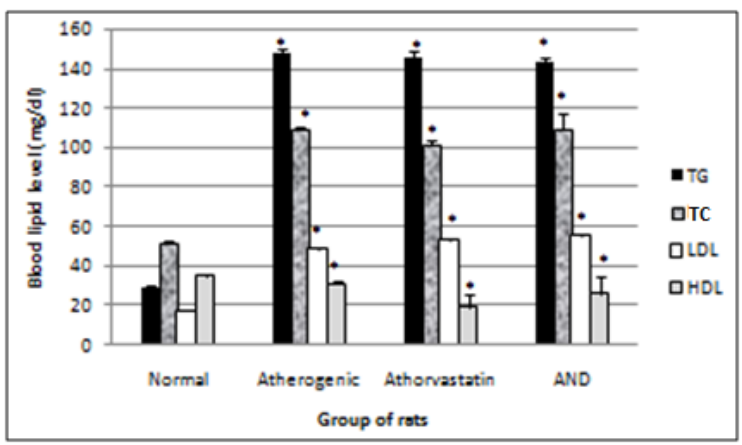

Fig. 2: Blood lipid level of rats after fed with atherogenic diet for $60 \mathrm{~d}(*(\mathrm{P}<0.05)$ significantly different with normal rats)

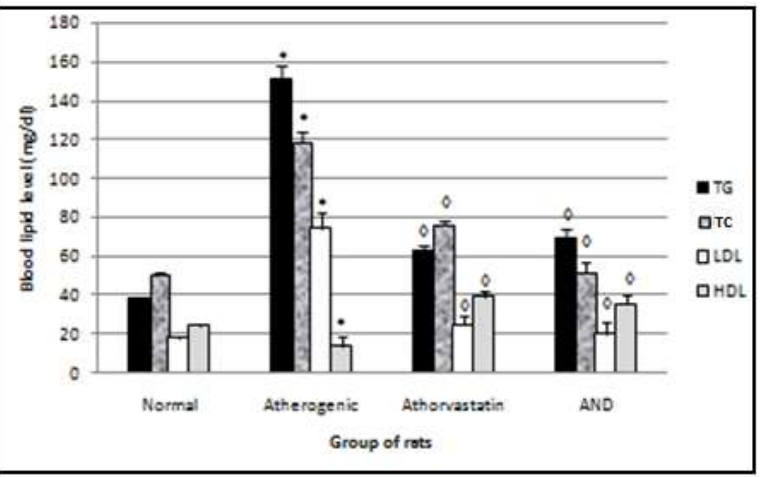

Fig. 3: Blood lipid level of rats after fed with atherogenic diet for $60 \mathrm{~d}$ and continuing with combination atherogenic diet+AND and atherogenic diet+Atorvastatin $(*(P<0.05)$ significantly different with normal rats, $\diamond$ significantly different with atherogenic rats)

\begin{abstract}
Antioxidant activity
The result showed that administration of AND for four weeks to the rats (which were fed with atherosclerotic diet) could significantly decrease ox-LDL concentration in the blood when compared to the atherogenic group. On the 1st week, the ox-LDL concentration of AND group was as high as the atherogenic group. The ox-LDL concentration of AND group in the 4th week was lower than the ox-LDL concentration of AND group in the previous week. If AND and atherosclerosis group were compared on the 4th week, the ox-LDL concentration was significantly different. We can conclude that AND had antioxidant property by preventing LDL oxidation. The ox-LDL concentration from atorvastatin group in the 4th week was lower than the ox-LDL concentration of atorvastatin group in the previous week. If atorvastatin and atherosclerosis group were compared on the 4th week, the ox-LDL concentration was significantly different. If AND and atorvastatin group were compared on the 4th week, the ox-LDL concentration was not significantly different.
\end{abstract}

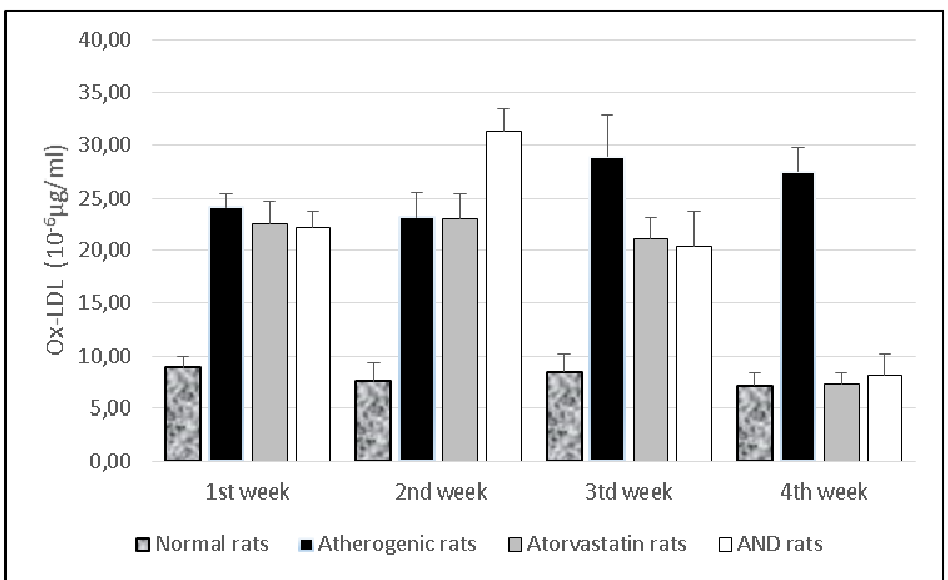

\begin{tabular}{|c|c|c|c|c|}
\hline Normal rats & $8.94 \pm 1.04$ & $7.58 \pm 1.76$ & $8.48 \pm 1.72$ & $7.14 \pm 1.23$ \\
\hline Atherogenic rats & $24.12 \pm 1.28^{*}$ & $23.18 \pm 2.38^{*}$ & $28.90 \pm 4.01^{*}$ & $27.47 \pm 2.30^{*}$ \\
\hline Atorvastatin rats & $22.51 \pm 2.22^{*}$ & $23.05 \pm 2.38^{*}$ & $21.08 \pm 2.10^{*}$ & $7.28 \pm 1.10$ \\
\hline AND rats & $22.20 \pm 1.52^{*}$ & $31.41 \pm 2.07^{*}$ & $20.36 \pm 3.39^{*}$ & $8.13 \pm 2.08$ \\
\hline
\end{tabular}

Fig. 4: Ox-LDL concentration (mean \pm SD) each week for one month for AND rats, atorvastatin rats, atherogenic rats and normal rats $(*(P<0.05)$ significantly different with normal rats)

\section{Morphological structure of aorta's rats}

Aorta' slide was made every week for one month. Each group of the rats was killed, and the aorta's rat was observed. From the morphological structure of aorta's rat, atherosclerosis was scored as follows: on 4 point: 0 , normal; 1 , widening of elastic fibers with few foam cells; 2 , fragmentation of elastic lamellae with numerous foam cells and fibrosis; 3 , smooth muscle cells proliferation, medial lipid infiltration and fibrosis; 4, lipid-calcic plaque or ulcerated plaque [10]. 
Table 1: Distribution of aortic atherosclerosis scores at D90 in two groups of rat receiving atherogenic diet $(n=4)$

\begin{tabular}{|c|c|c|c|c|c|c|c|c|c|c|c|c|c|c|c|c|}
\hline Lesions scores & A1 & A2 & A3 & A4 & B1 & B2 & B3 & B4 & C1 & $\mathrm{C} 2$ & C3 & C4 & D1 & D2 & D3 & D4 \\
\hline 0 & - & - & 1 & 3 & - & - & - & 2 & - & - & - & - & 3 & 4 & 3 & 3 \\
\hline 1 & 1 & 3 & 3 & 1 & 1 & 1 & 2 & 2 & 2 & - & - & - & - & - & 1 & 1 \\
\hline 2 & 3 & 1 & - & - & 2 & 1 & 1 & - & - & 1 & 1 & 1 & - & - & - & - \\
\hline 3 & - & - & - & - & 1 & 2 & 1 & - & 2 & 2 & 1 & 1 & - & - & - & - \\
\hline 4 & - & - & - & - & & - & - & - & - & 1 & 2 & 2 & - & - & - & - \\
\hline
\end{tabular}

$\mathrm{A} 1, \mathrm{~A} 2, \mathrm{~A} 3$, A4 is morphological structure of aorta's AND rats fed atherogenic diet for 2 mo and continuing with AND for $1 \mathrm{w}, 2 \mathrm{w}, 3 \mathrm{w}$ and $4 \mathrm{w}$; B1, $\mathrm{B} 2, \mathrm{~B} 3, \mathrm{~B} 4$ is morphological structure of aorta's atorvastatin rats fed atherogenic diet for 2 mo and continuing with atorvastatin for $1 \mathrm{w}, 2 \mathrm{w}, 3 \mathrm{w}$ and 4 w; C1, C2, C3, C4 is morphological structure of aorta's rats fed atherogenic diet for 9th week, 10th week, 11th week, 12th week; D1, D2, D3, D4 is morphological structure of aorta's rats fed normal diet for 9th week, 10th week, 11th week, 12th week.

The rats $(\mathrm{n}=4)$ from each group were sacrificed every week to observe the morphological structure of the aortas. From the lesions, it showed that AND could help chance severity aortic atherosclerosis. The score varied from group A1 until group A4. The aorta morphology of group A1 showed that one aorta had a widening of elastic fibers with few foam cells (score 1) and three aortas had the proliferation of smooth muscle cells (score 3) (fig. 5 A1). AND administration for four weeks could repair aorta condition. Group A4' aorta morphology showed that three aortas became normal (score 0) and one aorta still had a widening of the first interlamellar (score 1) (fig. 5 A4). Atorvastatin administration could also help changing the severity of aortic atherosclerosis. The score also varied from group B1 until group B4. The aorta morphology of group B1 showed that one aorta had a widening of elastic fibers with few foam cells (score 1), two aortas had fragmentation of elastic lamellae with numerous foam cells and fibrosis (score 2), and one aorta had the proliferation of smooth muscle cells (score 3) (fig. 5 B1). Atorvastatin administration for four weeks could improve aorta condition. Group B4' aorta morphology showed that two aortas became normal (score 0) and two aortas still had a widening of the first interlamellar (score 1) (fig. 5 B4). Contrarily, the morphological structure of atherogenic rats was getting worse week by week.

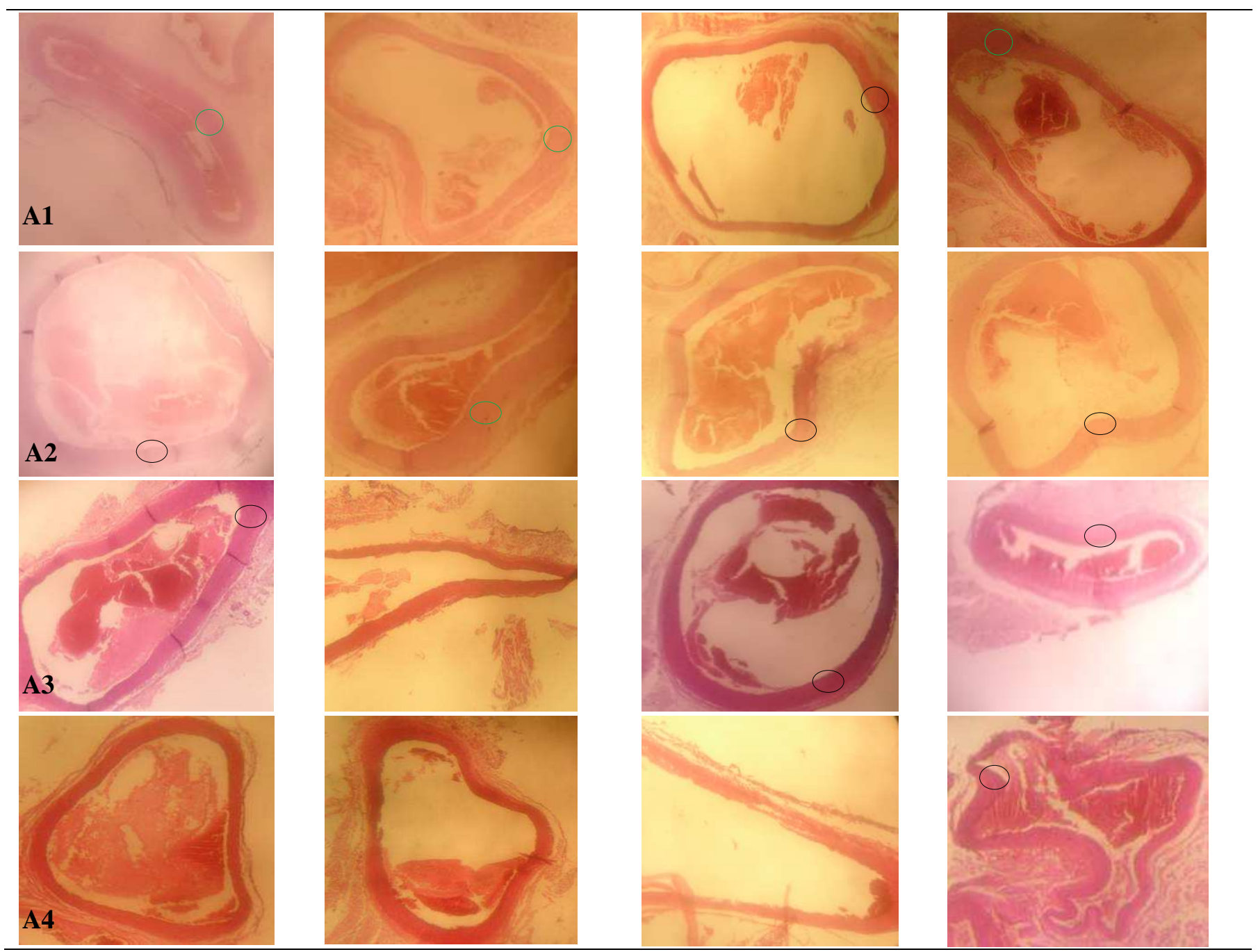




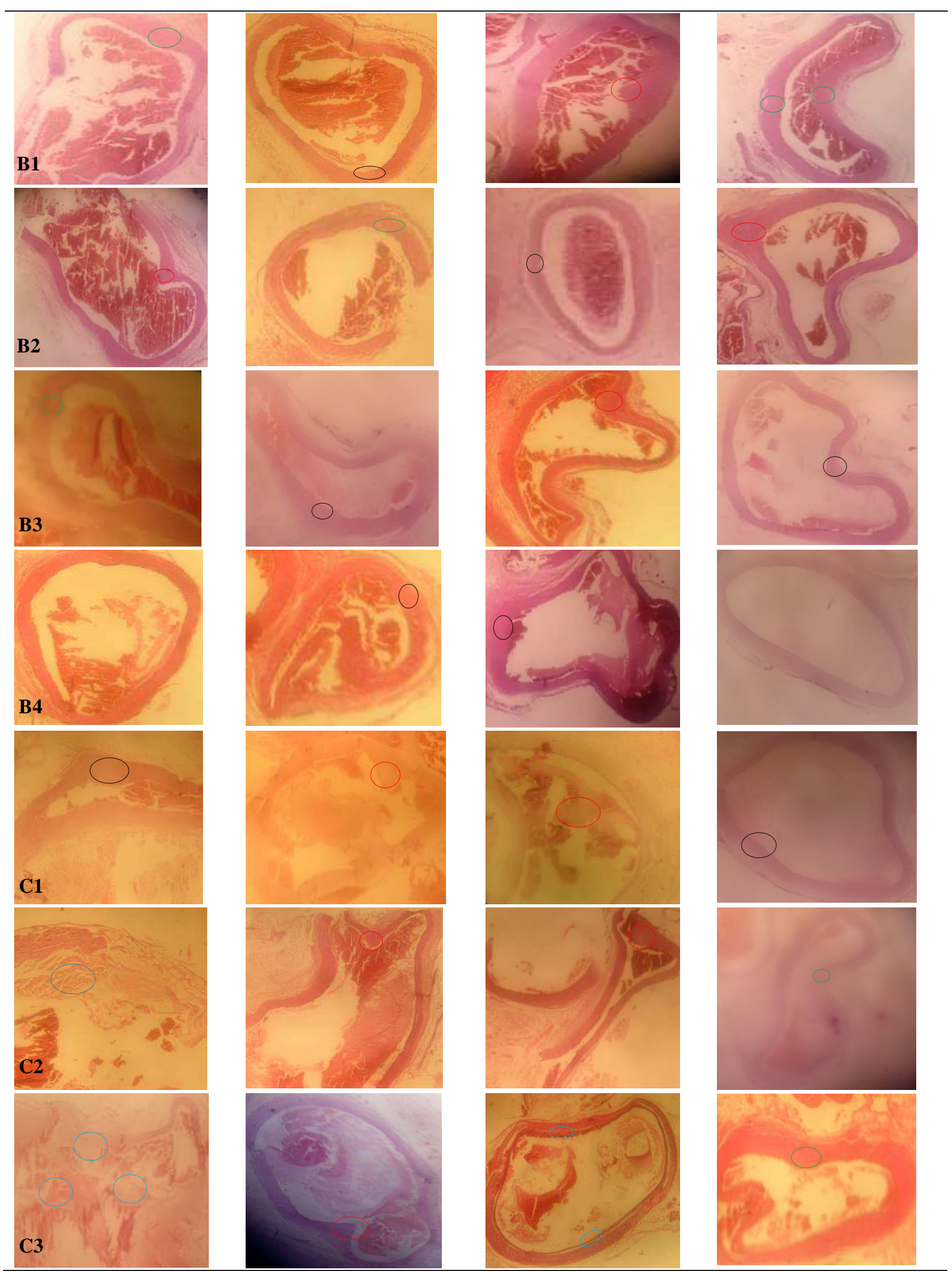



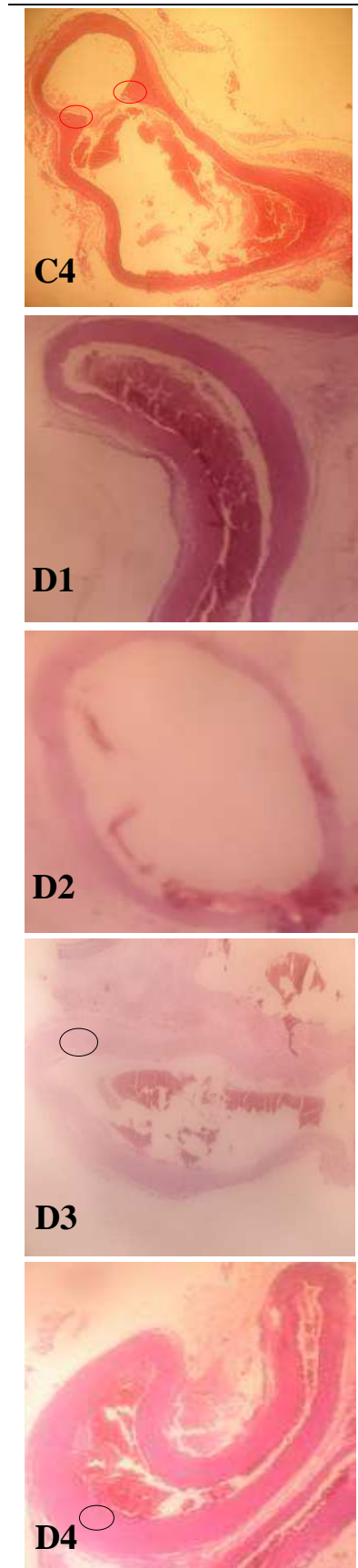
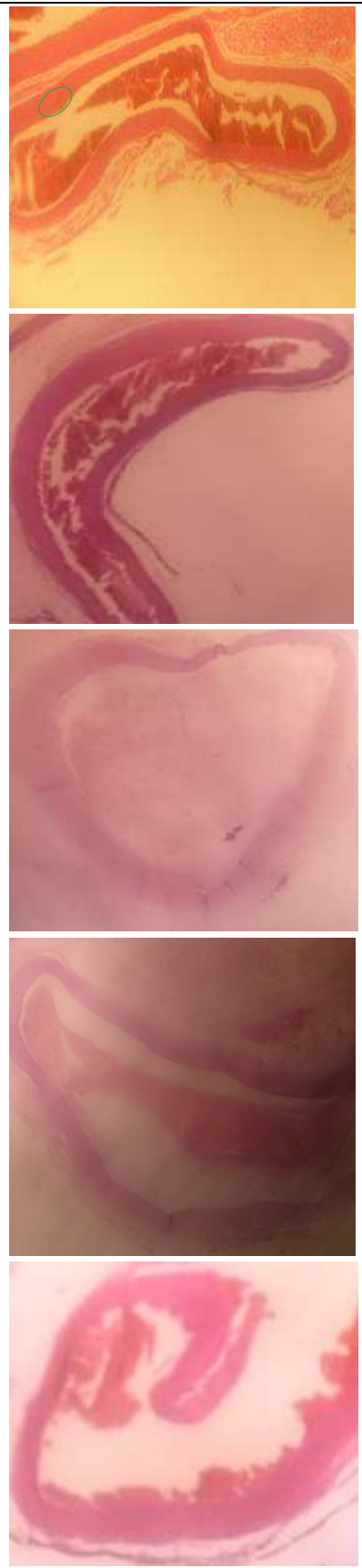
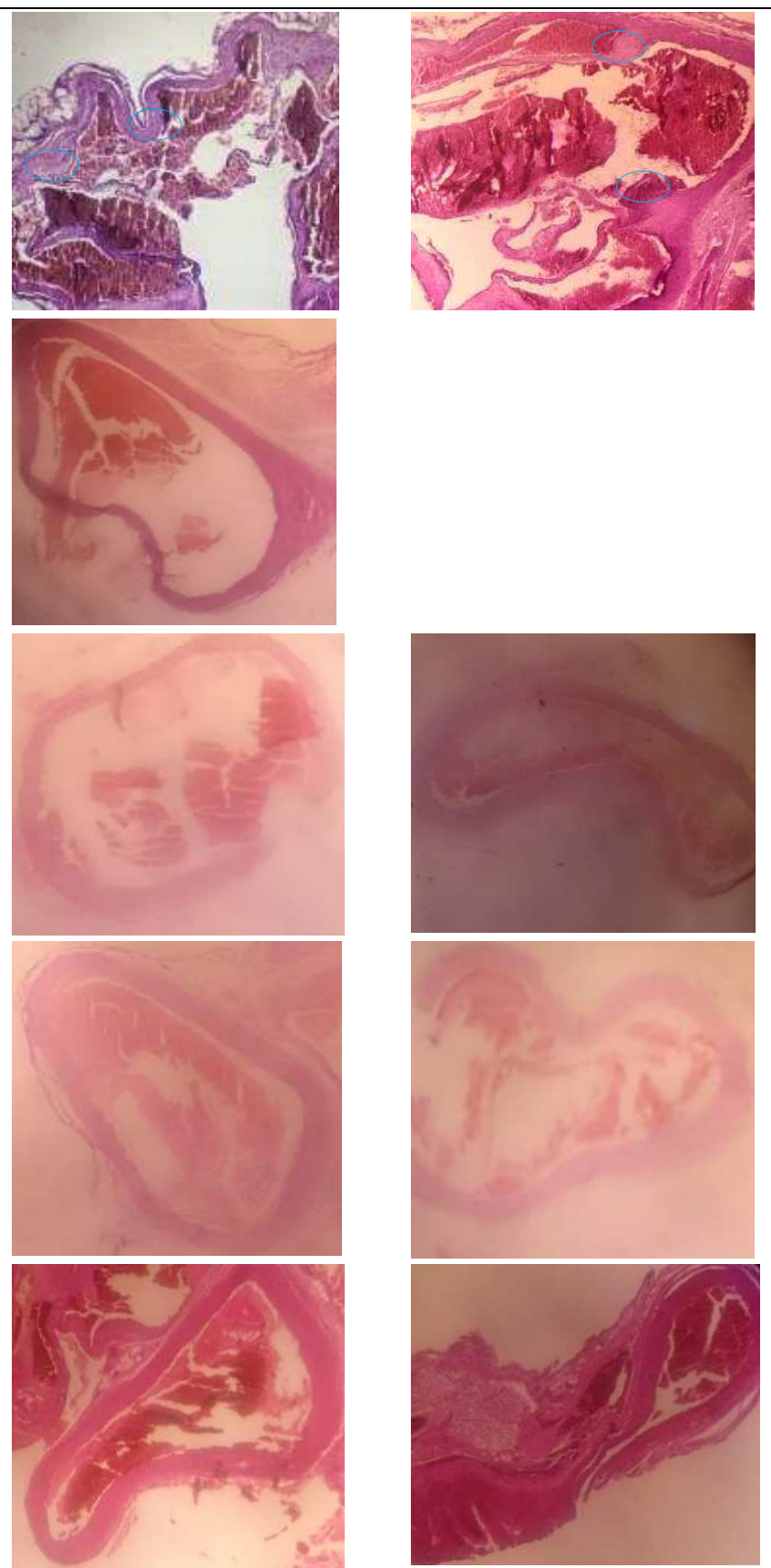

Fig. 5: Morphological structure of aorta in albino Wistar male rats 40x. A1, A2, A3, A4 is morphological structure of aorta's AND rats fed atherogenic diet for 2 mo and continuing with AND for $1 \mathrm{w}, 2 \mathrm{w}, 3 \mathrm{w}$ and $4 \mathrm{w}$; B1, B2, B3, B4 is morphological structure of aorta's atorvastatin rats fed atherogenic diet for 2 mo and continuing with atorvastatin for $1 \mathrm{w}, 2 \mathrm{w}, 3 \mathrm{w}$ and $4 \mathrm{w} ; \mathrm{C1}, \mathrm{C2}, \mathrm{C3}, \mathrm{C4}$ is morphological structure of aorta's rats fed atherogenic diet for 9th week, 10th week, 11th week, 12th week; D1, D2, D3, D4 is morphological structure of aorta's rats fed regular diet for 9 th week, 10th week, 11th week, 12th week. Black circle $(0)=$ score 1; green circle $(0)=$ score 2 ; red circle $(0)$ = score 3 ; blue circle $(0)=$ score 4

\section{DISSCUSION}

AND compound had been successfully separated by the recrystallization method. AND compounds' melting point was also tested to ensure the accuracy of the compound. Melting point result of AND was $229^{\circ} \mathrm{C}$. Based on the literature, melting point of AND was $228^{\circ} \mathrm{C}-230^{\circ} \mathrm{C}[11]$.

Atherogenic diet administration (15\% pig fat, $10 \%$ yolk, $1 \%$ calcium, and 20,000 IU vitamin D3 wly) for $60 \mathrm{~d}$ in rats could cause a significant difference of lipid profile compared to normal rats $(\mathrm{p}<0.05)$. Unsaturated fat contained in lard was $25 \%$ higher than the chicken fat and 1,2\% higher than the cow fat [12]. Therefore, food which was combined with lard could increase TC and LDL and also could decrease HDL. The result showed that rats' profile lipid was different between normal group rat and the other groups. Lipid profile of TG, TC, and LDL was higher and significantly different with normal group $(\mathrm{p}<0.05)$ but HDL was lower and also significantly different with normal group $(\mathrm{p}<0.05)$ (fig. 2). Atherosclerosis could be induced by yolk because it contained $20 \mathrm{mg} / \mathrm{gr}$ cholesterol [13].

AND could lower TG, TC, and LDL due to by sambiloto water extract (probably contain AND compound) which had the ability as in vitro HMG co-A reductase inhibitor [22]. AND was capable of doing an in silico inhibition enzyme HMG co-A reductase, so TC level in the blood 
could be decreased as well. AND could induce LCAT enzyme activity (Lecithin Cholesterol Acyl-Transferase) that would make HDL increased [14]. Andrographis paniculata purified extract could significantly decrease lipid profile of TG, TC, and LDL compared to the atherogenic group and could also significantly increase HDL level compared to the atherogenic group.

Oxidative stress occured because of an imbalance between free radicals and antioxidant defences production which led to cell function deregulation [15]. An antioxidant is a substance that significantly delayed or prevented oxidation prosses of a readily oxidizable substrate at low concentration. Antioxidant compounds and enzymes in the body were not entirely sufficient to prevent dangerous oxidation, especially hyperlipidemia and diabetes conditions in which free radicals were excessively being produced [16]. The primary purpose of antioxidant was to help the body to protect against damage caused by reactive oxygen species (ROS) [17]. The methanolic extract of A. paniculata had property as antioxidant towards DPPH, lipid peroxidation, and DNA cleavage protective assay [18].

Dyslipidemia is characterised by the LDL increase which could induce oxidation of LDL into ox-LDL. The increase ox-LDL could induce forming of foam cells in tunica intima and tunica media. Accumulation of foam cells in tunica intima and tunica media (interlamellar space) could induce atherosclerotic condition.

The LDL level increase in the blood would lead to an increase in oxidized LDL levels because LDL oxidation is likely to occur in the aorta [18]. The presence of oxidized LDL-induced smooth muscle cell proliferation and eventually, it would become atherosclerotic lesions. The atherogenic group had the highest levels of oxidized LDL. Atherogenic control rats had changes in morphology of the aorta (fig. 5 C1-4). We could say AND and atorvastatin had the same property as an antioxidant. AND compound was expected to be able to prevent foam cells formation. By preventing the foam cells formation, the accumulation of foam cells in tunica intima and tunica media would not happen. Atherosclerosis happened not only because of a high level of ox-LDL concentration in the blood but also because of inflammation processes.

The atherogenic diet that was given to the rats for $60 \mathrm{~d}$ could increase TC and LDL levels in the rats' blood. The LDL level increase would induce an increase in Ox-LDL. Ox-LDL would stimulate an inflammatory reaction, thereby causing foam cells formation. There was a positive correlation between high ox-LDL level, lipid blood (total cholesterol, triglyceride, LDL) which contributed to the aggravation of the atherogenesis process through the increase of monocytes accumulation and various other processes [20]. One transcription factor that played a significant role in the inflammatory reaction was NF-kB and activated NF-kB was presented in endothelial cells, SMC, and macrophages in atherosclerotic plaques [21]. AND was able to bind and inhibit the activation of NF-kB protein (in silico) so allegedly capable of preventing inflammatory reaction occurrence in the aorta.

\section{CONCLUSION}

$18 \mathrm{mg} / \mathrm{kg}$ BW AND compound from sambiloto herb showed the antidyslipidemic and antioxidant effect in atherogenic rats. AND compound for four weeks in atherogenic rats could protect and prevent the severity of vascular atherosclerosis process.

\section{ACKNOWLEDGEMENT}

We gratefully thank Universitas Udayana Bali Indonesia through Hibah Bersaing Research Grand 2015 and Ristekdikti.

\section{CONFLICTS OF INTERESTS}

Declared none

\section{REFERENCES}

1. Akbar S. Andrographis paniculata: a review of pharmacological activities and clinical effects. Napa: LLC; 2011. p. 66-77.
2. Negi AS, Kumar JK, Luqman S, Sbanker K, Gupta MM, Kbanuja SPS. Recent advances in plant hepatoprotectives: a chemical and biological profile of some important leads. Med Res Rev 2008;28:821.

3. Roxas M, Jurenka J. Colds and influenza: a review of diagnosis and conventional, botanical and nutritional considerations. Altern Med Rev 2007;12:25-48.

4. Cheung HY, Cheung CS, Kong CK. Determination of bioactive diterpenoids from Andrographis paniculata by micellar electrokinetic chromatography. J Chromatogr 2001;930:171-6.

5. Brown SM, Goldstein LJ. A receptor-mediated pathway for cholesterol homeostasis. Science 1986;232:34-7.

6. William I. The pathology of atherosclerosis: plaque development and plaque responses to medical treatment. Am J Med 2009;122:S3-14.

7. Parthasarathy S, Wieland E, Steinberg D. A role for endothelial cell lipoxygenase in the oxidative modification of low density lipoprotein. Proc Natl Acad Sci U S A 1989;86:1046-50.

8. Martha S, Akula A, Yellu NR. Anti-atherosclerotic effect of atorvastatin and clopidrogel alone and combination in rats. Int J Evol Biol 2008;46:698-703.

9. Takahashi K, Takeya M, Sakashita N. Multifunctional roles of macrophages in development and progression of atherosclerosis in human and experimental animals. Med Electron Microsc 2002;35:179-203.

10. Bennani-Kabchi NL, Kehel F, El B, Fdhil H, Amarti A, Saidi AG. New model of atherosclerosis in insulin resistant sand rats: hypercholesterolemia combined with D2 vitamin. Atherosclerosis 2000;150:55-61.

11. Wongkittipong R, Prat S, Gourdon C. Solid-liquid extraction of andrographolide from plants experimental study, kinetic reaction and model. Sep Purif Technol 2004;40:147-54.

12. Hermanto S, Muawanah A, Harahap R. Kadar dan karakteristik lemak hewani (Ayam, Sapi dan Babi) hasil analisa FTIR dan GCMS. J Valensi 2008;1:102-9.

13. Harini M, Astirin OP. Kadar kolesterol darah tikus putih (Rattus novergicus) hiperkolesterolemik setelah perlakuan VCO. Bioteknologi 2009;6:55-62.

14. Lakshmia V, Srivastav S, Khanna AK, Mahdi AA, Agarwal SK. Lipid lowering potential of Andrographis paniculata (Nees). J Phytopharmacol 2014;3:124-9.

15. Ravi K, Ramachandran B, Subramanian S. Effect of Eugeniajambolana seed kernel on antioxidant defensesystem in streptozotocin induced diabetes in rats. Life Sci 2004;75:2717-31.

16. Brown SL. Lowered serum cholesterol and low mood. Br Med J 1996;313:637-8.

17. Shahidi F. Natural Antioxidant, Chemistry, Health Effect and Application, AOCS. Press Champaign, Illinois; 1997. p. 1-23.

18. Huidrom S, Deka M. Determination of antioxidant property of Andrographis paniculata. Indian J Drugs Diseases 2012;1:12-7.

19. Maiolino G, Rossitto G, Caielli P, Bisogni V, Rossi GP, Calo LA. The role of oxidized low-density lipoproteins in atherosclerosis: the myths and the facts. Med Inflamm 2013. p. 1-13.

20. Steinberg D, Witztum JL. Lipoproteins and atherogenesis. Curr Concepts J Am Med Assoc 1990;264:3047-52.

21. Brand K, Page S, Rogler G, Bartsch A, Brandl R, Knuechel R, et al. Activated transcription factor nuclear factor-kappa $\mathrm{B}$ is present in the atherosclerotic lesion.J Clin Invest 1996;97:1715-22.

22. Patel D, Hirangi, Gaurang BS, Vandit T. Investigation of HMG Co A reductase inhibitory activity of antihyperlipidemic herbal drugs in vitro study. Asian J Exp Biol Sci 2011;2:63-8.

23. Kesh SB, Sarkar D, Manna K. High-fat diet-induced oxidative stress and its impact on metabolic syndrome: a review. Asian J Pharm Clin Res 2016;9:47-52.

\section{How to cite this article}

- $\quad$ Ni Kadek Warditiani, Ni Made Pitri Susanti, Cokorda Istri Sri Arisanti, Ni Putu Rika Dharma Putri, I Made Agus Gelgel Wirasuta. Antidyslipidemic and antioxidant activity of andrographolide compound from sambiloto (Andrographis paniculata) herb. Int J Pharm Pharm Sci 2017;9(7):59-65. 